\title{
Laelia furfuracea Lindl.: an Endemic Mexican Orchid with Anticoagulant Activity
}

Abimael López-Pérez ${ }^{1}$, Jesús Hernández-Juárez ${ }^{2}$, Rodolfo Solano ${ }^{1}$, Abraham Majluf-Cruz ${ }^{3}$, Pedro Antonio Hernández-Cruz ${ }^{4}$, Luicita Lagunez-Rivera ${ }^{1 *}$

${ }^{1}$ Laboratorio de Extracción y Análisis de Productos Naturales Vegetales, Centro Interdisciplinario de Investigación para el Desarrollo Integral Regional Unidad Oaxaca, Instituto Politécnico Nacional. Santa Cruz Xoxocotlán, Oaxaca, México.

${ }^{2}$ CONACYT-Facultad de Odontología, Universidad Autónoma Benito Juárez de Oaxaca, México.

${ }^{3}$ Unidad de Investigación Médica en Trombosis, Hemostasia y Aterogénesis, Hospital General Regional No.1 Dr. Carlos Mac Gregor Sánchez Navarro, IMSS, Ciudad de México.

${ }^{4}$ Laboratorio de genómica, proteómica y glicobiología del cáncer, Facultad de Medicina y Cirugía, Universidad Autónoma Benito Juárez de Oaxaca, México.

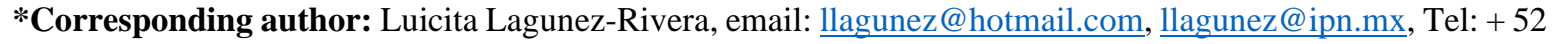
9515170610.

Received May 21 ${ }^{\text {st }}, 2021 ;$ Accepted September $8^{\text {th }}, 2021$.

DOI: http://dx.doi.org/10.29356/jmcs.v66i1.1588

\begin{abstract}
Laelia furfuracea is an endemic orchid from Mexico, with antioxidant activity. The objective of this study was to evaluate the effect of hydroethanolic extract and fractions obtained from the orchid leaves on the clotting times of patients with venous thromboembolic disease (VTD) and to identify their tentative compounds. The anticoagulant activity was evaluated by determining prothrombin (PT), thrombin (TT) and, activated partial thromboplastin (APTT) times. Identification of the compounds was carried out using a chromatographic technique with an ultra-high-performance liquid chromatographic analyzer coupled with electrospray ionization with quadrupole time of flight-mass-mass spectrometry. The extract prolonged the clotting times depending on the concentration-response $(5-60 \mathrm{mg} / \mathrm{mL}) ; 25 \mathrm{mg} / \mathrm{mL}$ prolonged the PT $(33.2 \pm 2.3 \mathrm{~s})$ and TT $(33.1 \pm 0.3 \mathrm{~s})$; and APTT $(61.8 \pm 3.4 \mathrm{~s})$ at a concentration of $15 \mathrm{mg} / \mathrm{mL}$. The main groups tentatively identified were xanthine, carboxylic acid, amino acid, and phenolic compounds. These compounds or the synergy between them prolong clotting times. Laelia furfuracea is an orchid with research potential in the search for new anticoagulant agents. Keywords: Phenolic compounds; clotting times; thrombin; UPLC-ESI-MS-qTOF.
\end{abstract}

Resumen. Laelia furfuracea es una orquídea endémica de México, la cual posee actividad antioxidante. El objetivo de este estudio fue evaluar el efecto del extracto hidroetanólico y fracciones obtenidas de hojas de la orquídea sobre los tiempos de coagulación de pacientes con enfermedad tromboembólica venosa (ETV) e identificar sus posibles compuestos. La actividad anticoagulante se evaluó determinando los tiempos de protrombina (TP), trombina (TT) y tromboplastina parcial activada (TTPA). La identificación de los compuestos se realizó usando una técnica cromatográfica con un analizador cromatográfico líquido de Ultra Alta Resolución con Ionización por electroespray acoplado a espectrometría de masas con Cuadrupolo y Tiempo de Vuelo. El extracto prolongó los tiempos de coagulación dependiente de la concentración-respuesta $(5-60 \mathrm{mg} / \mathrm{mL}) ; 25 \mathrm{mg} / \mathrm{mL}$ prolongó el TP $(33.2 \pm 2.3 \mathrm{~s})$ y TT $(33.1 \pm 0.3 \mathrm{~s}) ;$ y TTPA $(61.8 \pm 3.4 \mathrm{~s})$ a una concentración de $15 \mathrm{mg} / \mathrm{mL}$. Los principales grupos de posibles compuestos identificados fueron xantina, ácido carboxílico, aminoácido y compuestos fenólicos. Estos compuestos o la sinergia entre ellos prolongan los 
tiempos de coagulación. Laelia furfuracea es una orquídea con potencial en investigación para la búsqueda de nuevos agentes anticoagulantes.

Palabras clave: Compuestos fenólicos; tiempos de coagulación; trombina; UPLC-ESI-MS-qTOF.

\section{Introduction}

Plant extracts with antioxidant properties have anticoagulant potential [1], which is attributed to the phenolic compounds they have [2]. Phenolic compounds have been reported to protect vascular health [3], reduce the risk of developing cardiovascular and cerebrovascular diseases [4,5], decrease fibrinogen concentration, improve antithrombin activity [6], have an antithrombotic effect by inhibiting platelet activity and active coagulation factors $\mathrm{X}$ and II $[7,9,10]$. This has contributed to the search for new inhibitors of the amidolytic activity of activated factor $\mathrm{X}(\mathrm{FXa})$, among which are the flavonoids procyanidin $\mathrm{B} 2$, cyanidin, quercetin, and silybin [7]. It has also been suggested that the -OH group of the $\beta$ ring of flavonoids structures increase the inhibition of FXa [1] and thrombin [11]. However, it is not clear how these compounds act on the coagulation system. In the liquid phase of hemostasis, there are two activation pathways, intrinsic and extrinsic, which converge in the activation of FX. The current cellular model considers that clot formation occurs in three phases. At initiation, once tissue factor (TF), and factor VII (FVII) are exposed, they promote the activation of FX, FIX, and FVII, producing small amounts of thrombin and platelet activation. In amplification, thrombin activates FIX, FVIII, and FV, releasing the content of the alpha granules from the activated platelet generating large amounts of thrombin. In the third phase, fibrinogen is transformed into fibrin [12,13].

Phytochemical studies in orchids show phenols in their extracts, such as flavonoids and phenolic acids, which could have therapeutic properties to be used in thrombotic conditions [14]. In traditional medicine, Prosthechea karwinskii named as ita ndeka (flower that grows on oak in Mixtec language) amarilla, monja amarilla (yellow nun in Spanish) [15], Catasetum integerrimum named as Ch'it ku'uk (inside inflamation) in Maya, Rhyncholaelia digbyana [16], Bletilla striata [17], and Laelia autumnalis, known in Spanish as flor de las ánimas (flower of all souls), flor de Todos los Santos (Flower of all saints), lirio de San Francisco (lily of Saint Francisco), gallito (cocky) [18] are used to heal wounds [19]; Calanthe discolor and C. liukiuensis increase blood flow [20]; some Dendrobium species promote regulation of blood pressure [21], and components of $D$. densiflorum show antiplatelet activity [22]. Bletilla striata stops wound bleeding [23] and increases platelet aggregation [24]. Laelia anceps has cytotoxic [25] and antihypertensive [26,27] activity, while L. autumnalis and $L$. speciosa have vasorelaxant activity [26,28,29].

Laelia furfuracea Lindl. is an endemic orchid to Mexico, it is distributed in the mountains that surround the Central Valleys of Oaxaca, where it grows as an epiphyte in Quercus or Quercus-Pinus forests [30]. It is used by some indigenous communities, especially the Mixtec ethnic group, as a ceremonial plant during the Christmas festivities [31]. In the literature, there are no reports on medicinal uses for this orchid by any ethnic group in Oaxaca. However, in a Mixtec community (San Pedro and San Pablo Teposcolula) one of the coauthors (RS) was informed about an herbal remedy for L. furfuracea, which consists of preparing an infusion of flowers that is drunk to treat cough. López et al., [32] reported that L. furfuracea has antioxidant activity.

Venous thromboembolic disease (VTD) includes deep vein thrombosis (DVT) and pulmonary embolism (PE); these diseases represent a public health problem since statistics show that 1 in 4 individuals worldwide dies from these conditions [33]. In Mexico, it is estimated that there is an incidence between 400 to 500 thousand cases per year, being one of the diseases with high mortality [34], which implies a high consumption of anticoagulants for its treatment. However, these drugs are not always safe and effective for patients [1], some require frequent monitoring and dose adjustment, such as vitamin $\mathrm{K}$ antagonists [35]. For this reason, the discovery of new agents with anticoagulant potential is important. Some species of orchids may be candidates for this type of study due to their medicinal uses and the presence of phenolic compounds. Due to this and the antioxidant activity of $L$. furfuracea, the hypothesis proposed is that the extract and fractions of this species will prolong clotting times, thus having anticoagulant activity. Derived from this, the aim of the study was to evaluate the effect of the hydroethanolic foliar extract of $L$. furfuracea, as well as its organic 
fractions, on the coagulation times in samples of patients with VTE and to tentative identify compounds. Venous thromboembolic disease (VTD) includes deep vein thrombosis (DVT) and pulmonary embolism (PE); these diseases represent a public health problem since statistics show that 1 in 4 individuals worldwide dies from these conditions [33]. In Mexico, it is estimated that there is an incidence between 400 to 500 thousand cases per year, being one of the diseases with high mortality [34], which implies a high consumption of anticoagulants for its treatment. However, these drugs are not always safe and effective for patients [1], some require frequent monitoring and dose adjustment, such as vitamin K antagonists [35].

\section{Experimental}

\section{Vegetal material}

The vegetal material of L. furfuracea was collected in the municipality of Santo Domingo Yanhuitlán,

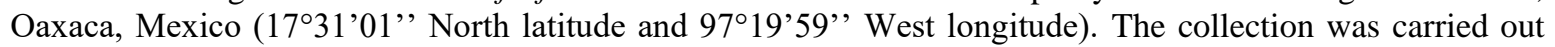
with the permission of the authorities of the Commissariat of Communal Property and the license of the Secretaría de Medio Ambiente y Recursos Naturales (SEMARNAT) granted to RS. A voucher specimen was herborized and deposited in OAX Herbarium (OAX-FLO-129-0402) of the Centro Interdisciplinario de Investigación para el Desarrollo Integral Regional Oaxaca, Instituto Politécnico Nacional, (R. Solano 4244) which was taxonomically determined by RS.

\section{Leaves extraction}

Only the leaves were obtained from the vegetal material, which were dehydrated at $40{ }^{\circ} \mathrm{C}$, pulverized in an M20 IKA WERKE (256890) mill, and subject to a solid-liquid extraction in Soxhlet equipment. The extraction was carried out with $5 \mathrm{~g}$ of foliar material using as a solvent a water-ethanol mixture in a 1:1 ratio, at a temperature of $78.2{ }^{\circ} \mathrm{C}$ for $2 \mathrm{~h}$.

\section{Fractions of the extract}

The extract was fractionated by increasing polarities [36,37], all solvents used were analytical grade (J. T. Baker). Fractionation process started by mixing in a separatory funnel equal volumes $(100 \mathrm{~mL})$ of the hydroethanolic extract and hexane, stirring vigorously for $5 \mathrm{~min}$ and constantly eliminating the pressure generated. From the two phases obtained, the organic fraction of hexane (Hexane) was separated from the aqueous phase containing the extract mixture. An equal volume of chloroform was added to this aqueous phase, it was mixed and stirred vigorously for $5 \mathrm{~min}$, it was left to stand for $15 \mathrm{~min}$ and the two phases were separated, which resulted in the fraction of chloroform $\left(\mathrm{CHCl}_{3}\right)$ and the other was aqueous. The same procedure described above was used with ethyl acetate and butanol to obtain the fractions of ethyl acetate (EtOAc), butanolic fraction (ButOH) and aqueous fraction $\left(\mathrm{H}_{2} \mathrm{O}\right)$ (according to Table 3). The extract and fractions were evaporated to dryness on a rotary evaporator (BUCHI, R-210) and stored at $5-10{ }^{\circ} \mathrm{C}$ until processing.

\section{Identification of compounds by UPLC-ESI-MS-qTOF}

The chromatographic separations were carried out with a UPLC liquid chromatography system (Thermo Scientific, Ultimate 3000) ESI-MS-qTOF in the Impact II equipment (Bruker Daltonics), with a negative ionization source. The column used was Thermo Scientific Acclaim $120 \mathrm{C} 18(2.2 \mu \mathrm{m}, 120 \AA, 50 \times$ $2.1 \mathrm{~mm})$. The mobile phase was A: $0.1 \%$ formic acid in water and B: acetonitrile. The gradient system: $0 \% \mathrm{~B}$ (0-2 min), $1 \%$ B (2-3 min), $3 \%$ B (3-4 min), $32 \%$ B (4-5 min), $36 \%$ B (5-6 min), $40 \%$ B (6-8 min), $45 \%$ B (8-9 min), 80\% B (9-11 min), $0 \%$ B (12-14). The injection temperature was $25{ }^{\circ} \mathrm{C}$. Diode Array Detector (DAD) analysis was run in the 200-800 $\mathrm{nm}$ range and set at 280 and $255 \mathrm{~nm}$. The mass spectrometer was operated in negative electrospray mode at $0.4 \mathrm{Bar}(5.8 \mathrm{psi})$, with a mass range of $50-1000 \mathrm{~m} / \mathrm{z}$, a flow rate of $0.35 \mathrm{~mL} / \mathrm{min}$, in autoMs. The ionization of the capillary voltage (Vcap) was $2700 \mathrm{~V}$ [38]. Internal calibration was carried out with sodium formate. Data were processed using Data Analysis for Mass Spectrometry software (Bruker Daltonics). Compounds were identified by comparing the mass spectra with MetaBase Bruker's, Plant metabolites, CompoundCrawler, and Bruker Sumner MetaboBase Plant Library. 


\section{Selection of patients}

The samples were obtained from patients with VTE who attended thrombophilia studies at the Unidad de Investigación Médica en Trombosis, Hemostasia y Aterogénesis of the Hospital General Regional No. 1, Dr. Carlos Mac-Gregor Sánchez Navarro, of the Instituto Mexicano del Seguro Social. All participants were informed about the study and their consent was requested to participate voluntarily, having to meet certain characteristics such as being older than 18 years, not being on anticoagulant drug therapy that will prolong clotting times. The results were compared with those obtained from a control plasma (plasma pool of 20 healthy donors). Samples from patients with lupus anticoagulant were discarded, as well as plasmas with evidence of lipemia or hemolysis. A minute was requested to the Institution's Ethics and Research Committee, which approved the research protocol.

\section{Obtaining platelet-poor plasma}

From the clinical samples obtained for thrombophilia studies, $5.4 \mathrm{~mL}$ of blood was taken from each patient and distributed in 2 vaccum plastic tubes (vacutainer ${ }^{\circledR}$ ) containing sodium citrate as an anticoagulant (3.2\%), maintaining a blood-anticoagulant ratio 9: 1. With this strategy, no additional venipuncture was required in the patients to obtain the study samples. Platelet poor plasma (PPP) was obtained after centrifuging the blood contained in the tubes at 2,500 x $\mathrm{g}$ for $15 \mathrm{~min}$. Aliquots of the plasma of $200 \mu \mathrm{L}$ were prepared in microvials, which were stored at $-80{ }^{\circ} \mathrm{C}$ until processing.

\section{Hemostatic tests}

These tests included the determination of clotting times. The clotting time was considered prolonged when the difference in seconds with respect to the coagulation time of the control plasma was $\geq 3 \mathrm{~s}$ for PT and TT, and $\geq 5 \mathrm{~s}$ for APTT. Commercial reagents (Neoplastin Plus, Asnieres, France and STA-APTT, Diagnostica Stago) and the standardized techniques available in an STA-COMPACT (Diagnostica Stago) equipment were used to determine the PT, TT, and APTT, with some modifications. To determine the PT, the patient's PPP was mixed with Owren Koller buffer (basal) or with orchid extract and fractions in a 2:1 ratio (previously diluted in Owren Koller). The effects of different concentrations of the extract $(5,10,15,20,25,30,35,40,45,50,55$ and $60 \mathrm{mg} / \mathrm{mL}$ ) and fractions $(1.0,2.5,5.0,10,12,14,16,18,20,22,24,26,28$ and $30 \mathrm{mg} / \mathrm{mL})$ at different incubation times $(0.5,1,2,5,10$ and $20 \mathrm{~min})$ were evaluated. The resulting extract or fraction with PPP was incubated at $37{ }^{\circ} \mathrm{C}$ for $180 \mathrm{~s}$; subsequently, $50 \mu \mathrm{L}$ of a calcium thromboplastin solution were added to $25 \mu \mathrm{L}$ of this mixture at $37^{\circ} \mathrm{C}$; the time of the appearance of the fibrin mesh was recorded with a coagulometer (STACOMPACT, Diagnostica Stago). To determine the APTT and TT, the PPP of the patients were treated under the same conditions as the PT. The APTT was determined by mixing $25 \mu \mathrm{L}$ of PPP (basal or post-extract) with $25 \mu \mathrm{L}$ of partial thromboplastin; the mixture was incubated for $180 \mathrm{~s}$ at $37^{\circ} \mathrm{C}$ and immediately, $25 \mu \mathrm{L}$ of $\mathrm{CaCl}_{2}$ $(0.25 \mathrm{M})$ were added and the clotting time was recorded. Finally, the TT was determined when $25 \mu \mathrm{L}$ of PPP (basal or post-extract) and $25 \mu \mathrm{L}$ of thrombin $(2 \mathrm{IU} / \mathrm{mL})$ were mixed and incubated for $180 \mathrm{~s}$ at $37^{\circ} \mathrm{C}$, recording the clotting time at the appearance of the fibrin mesh. Additionally, the effects of the extract $(25 \mathrm{mg} / \mathrm{mL})$ on thrombin time were evaluated using increasing concentrations of thrombin (1 to $40 \mathrm{IU} / \mathrm{mL}$ ). Unfractionated heparin $(5,000 \mathrm{IU} / \mathrm{mL}$; Inhepar) was used as a positive control for all coagulation tests.

\section{Statistical analysis}

The clotting times, measured in seconds, were expressed as mean \pm standard deviation of five-fold experiments. The clotting times recorded had a normal distribution (Shapiro Wilk test), so an ANOVA was used to determine significant variation among groups, while multiple comparisons of means were recorded with Newman Keuls test; both analyses were implemented in GraphPad Prism 9 software. Values with $p<0.05$ were considered as significantly different. 


\section{Results and discussion}

\section{Identification of phenolic compounds by UPLC-ESI-MS-qTOF}

The chromatogram of Fig. 1 shows the different phenolic tentative identified compounds in the $L$. furfuracea extract, some of them are reported in the literature as blood anticoagulants. These compounds are derived from flavonoids as kaempferol, luteolin, and phenolic acids, such as syringic acid acetate (Table 1). These compounds have been identified in other orchid genus as Eulophia, Cypripedium, Gastrodia, Bletilla, Bulbophyllum, Anoectochilus, Arundina, Eria, Malaxis, Habenaria, and Vanda [14], but they have not been identified in species of Laelia genus. In a previous study we reported the presence of flavonoids and tannins in L. furfuracea extract [32]. It is the only related study for this species, so all tentative compounds here have been identified for first time in L. furfuracea.

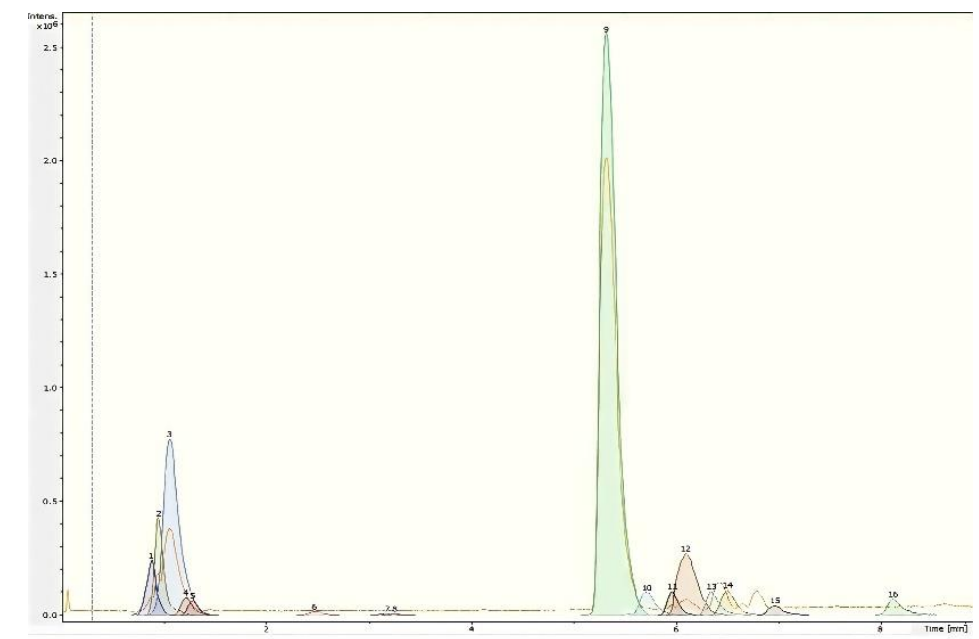

Fig. 1. UPLC-ESI-MS-qTOF chromatogram of the hydroethanolic extract of Laelia furfuracea leaves, the tentative identified compounds (negative ionization) were 1) 3-methylxanthine, 2) malic acid, 3) isocitric acid, 4) succinic acid, 5) O-methyl-D-glucopyranose, 6) protocatechuic acid, 7) rosmarinic acid, 8) tryptophan, 9) syringic acid acetate, 10) luteolin-7,3'-di-O-glucoside, 11) kaempferol-3-O-rutinoside, 12) kaempferol-7-Oglucoside, 13) apigetrin, 14) (+) - pinoresinol 4-glucoside, 15) N-acetyl-L-glutamine, 16) N-acetylarginine. The yellow continuous line represents the base chromatogram of the extract, and the color peaks represent the ion signals after deconvolution of the base chromatogram.

Syringic acid acetate was the compound with the highest intensity putatively identified in L. furfuracea leaves. It is derived from syringic acid, which is synthesized via shikimic acid pathway in plants. The reported activity for this compound is in prevention of cardiovascular diseases [39,40], as antioxidant [41,42], antiinflammatory, neuro and hepatoprotective [39]. The therapeutic property of syringic acid is attributed to the presence of methoxy groups at positions 3 and 5 of the aromatic ring, which confers its antioxidant capacity [39]. However, it is also reported a reduction of blood clotting time and procoagulant effect for syringic acid and protocatechuic acid present in Blumea riparia [43].

On the other hand, the protocatechuic acid is a member of catechols and a dihydroxybenzoic acid. It derives from a benzoic acid [44]. It has an antithrombotic effect [45], antiplatelet activity by reducing platelet aggregation mediated by blocking the interaction between von Willebrand factor (vWF) and glycoprotein Ib (GP Ib). In addition, this compound inhibits the shear- induced granular secretion of dense granules and $\alpha$ granules and attenuates GP IIb/IIIa activation [46]. Rosmarinic acid is a polyphenol derived from cinnamic acids and hydroxycinnamic acids [47], is an antioxidant [48-49], inhibits platelets [50], and has anticoagulant activity [51]. 
Table 1. Compounds tentative identified in the hydroethanolic extract of Laelia furfuracea leaves.

\begin{tabular}{|c|c|c|c|c|c|c|c|}
\hline $\begin{array}{c}\text { Peak } \\
\text { number }\end{array}$ & $\begin{array}{c}\text { Retention } \\
\text { time } \\
\text { (min) }\end{array}$ & $\begin{array}{c}\mathbf{m} / \mathbf{z} \\
{[\mathbf{M}-\mathbf{H}]^{-}}\end{array}$ & $\begin{array}{l}\text { Error } \\
\text { [ppm] }\end{array}$ & $\begin{array}{c}\text { Chemical } \\
\text { formula }\end{array}$ & Compound & Molecular structure & Compound type \\
\hline 1 & 0.9 & 165.0399 & 11.4 & $\mathrm{C}_{6} \mathrm{H}_{6} \mathrm{~N}_{4} \mathrm{O}_{2}$ & 3-Methylxanthine ${ }^{a}$ & & Xanthine \\
\hline 2 & 0.7 & 133.0137 & 3.8 & $\mathrm{C}_{4} \mathrm{H}_{6} \mathrm{O}_{5}$ & Malic acida & & Carboxylic acid \\
\hline 3 & 1.1 & 191.0192 & 2.9 & $\mathrm{C}_{6} \mathrm{H}_{8} \mathrm{O}_{7}$ & Isocitric acid ${ }^{a}$ & & Carboxylic acid \\
\hline 4 & 1.2 & 117.0188 & 3.9 & $\mathrm{C}_{4} \mathrm{H}_{6} \mathrm{O}_{4}$ & Succinic acid ${ }^{\mathrm{a}}$ & & Dicarboxylic acid \\
\hline 5 & 1.3 & 161.0450 & 3.4 & $\mathrm{C}_{7} \mathrm{H}_{14} \mathrm{O}_{6}$ & $\begin{array}{l}\text { O-Methyl-D- } \\
\text { glucopyranose }\end{array}$ & & Monosaccharide \\
\hline 6 & 2.5 & 153.018 & 2.9 & $\mathrm{C}_{7} \mathrm{H}_{6} \mathrm{O}_{4}$ & $\begin{array}{c}\text { Protocatechuic } \\
\text { acid }^{\mathrm{a}}\end{array}$ & & Phenolic acid \\
\hline
\end{tabular}




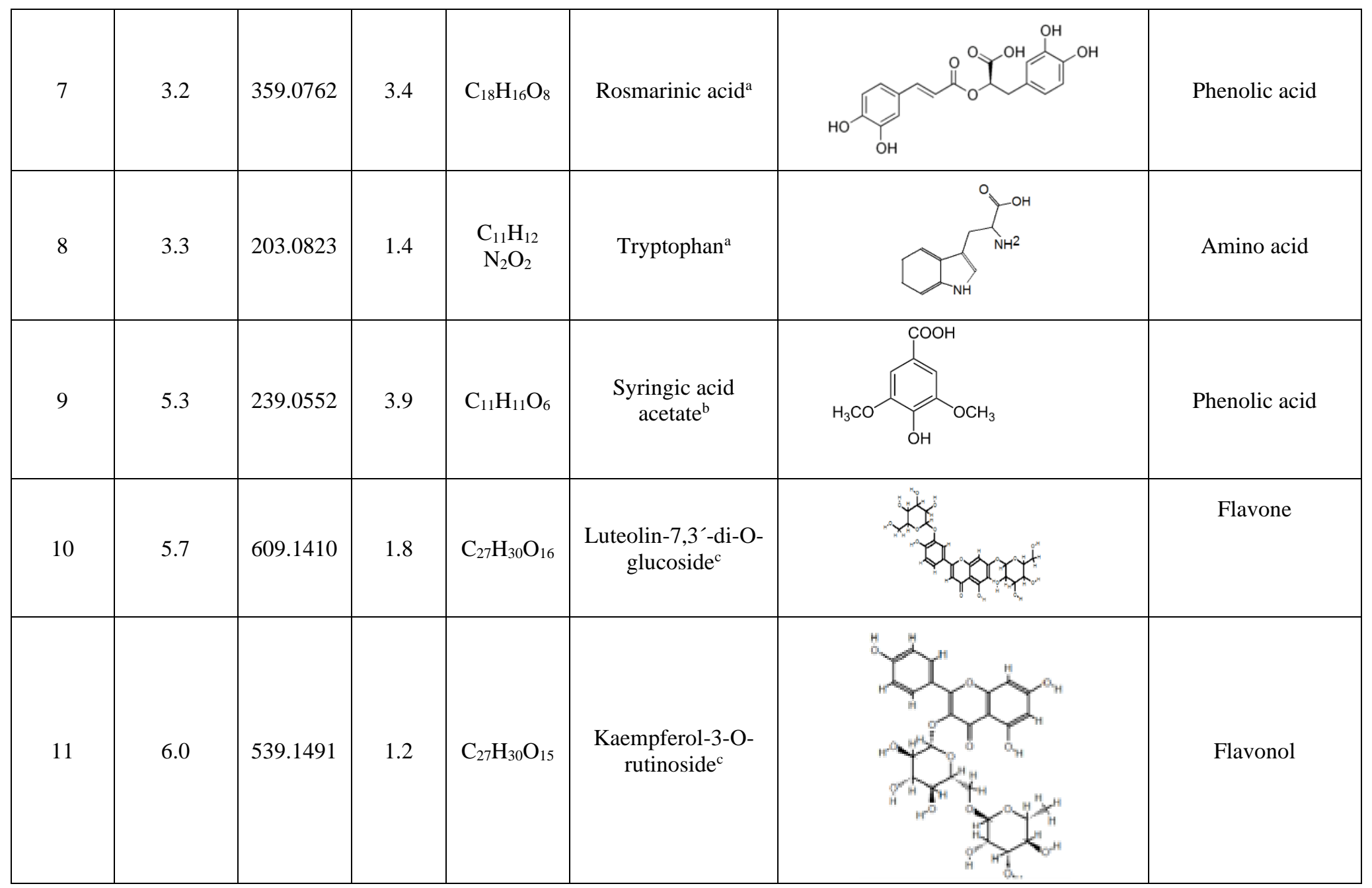




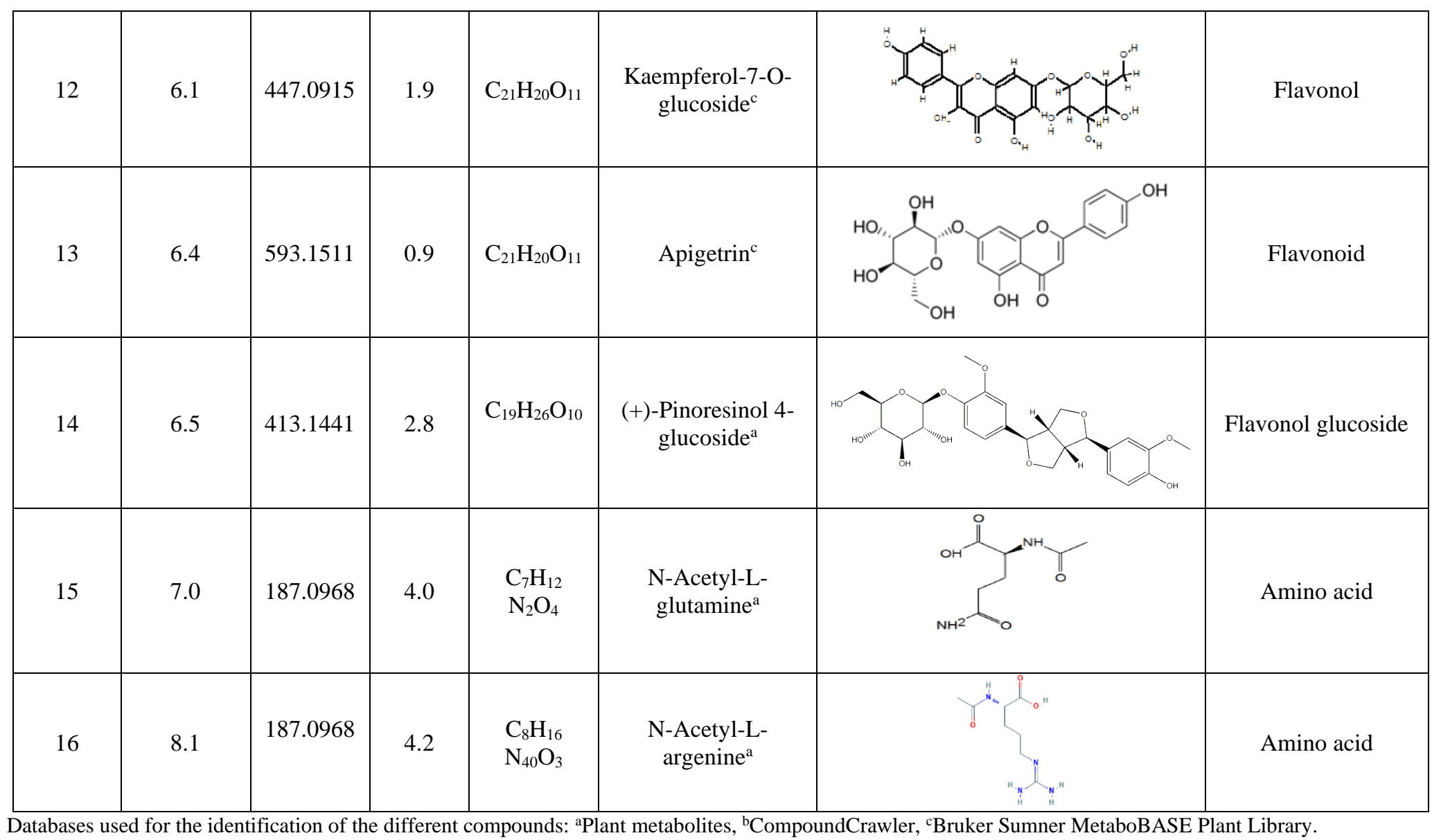


Flavonoids derived from luteolin show antiplatelet and vasorelaxant activity [52], and kaempferol such as Kaempferol-3-o-glucose, Kaempferol-3-o-glucose (2-1) rhamnose, Kaempferol-3-o-(2"-di-E-pcoumaroyl)rhamnoside, and Kaempferol-3-o-(2",4"-di-E-pcoumaroyl)-rhamnoside in other types of plants created an anticoagulant effect by prolonging PT and APTT $[11,53]$. The way flavonoids interact to inhibit FXa activity is by substituting the hydroxyl at the R1 and R2 position in the B ring of the flavonoid structure [7].

A database of bioactive at Chemical Entities of Biological Interest molecules with pharmaceutical properties [54-57] consulted executes the interaction between the molecular structure and the bioactivity of the compounds, in this case, syringic acid [54], protocatechuic acid [55], rosmarinic acid [56] and apigetrin [57] with coagulation FX. Thus, the scientific background and the consultation made in this database suggest that the tentatively identified phenolic compounds or the synergy between all the compounds present in the extract could be the bioactive agents responsible for the anticoagulant effect of $L$. furfuracea.

\section{Effect of hydroethanolic extract on clotting times}

The results of the clotting times of the patients with VTE show that the APTT is shortened compared to the control plasma $(30.7 \pm 2.2 \mathrm{~s}$ vs. $32.0 \pm 0.8 \mathrm{~s} ; \mathrm{p}=0.046)$, but not the PT $(13.4 \pm 1.4 \mathrm{~s}$ vs. $13.2 \pm 0.6 \mathrm{~s} ; \mathrm{p}=$ $0.235)$ and TT ( $16.1 \pm 1.6 \mathrm{~s}$ vs. $16.2 \pm 0.6 \mathrm{~s})$. Shortening of APTT may be due to thrombophilia in patients with VTE. Given this procoagulant scenario of the samples from patients with thrombosis, the anticoagulant activity of the orchid extracts was estimated as described below.

The hydroethanolic extract of $L$. furfuracea leaves prolonged the PT, APTT, and TT depending on the concentration-response. On average and, in comparison with the baseline time, the PT was prolonged from 13.7 $\pm 0.3 \mathrm{~s}$ to $49.1 \pm 0.8 \mathrm{~s}$ with the concentration of $25 \mathrm{mg} / \mathrm{mL}$ of the extract; under this same concentration, the TT was prolonged from $16.6 \pm 0.5 \mathrm{~s}$ to $30.1 \pm 0.9 \mathrm{~s}$; APTT lasted from $32.0 \pm 1.2$ to $61.8 \pm 3.4 \mathrm{~s}$ using a concentration of $15 \mathrm{mg} / \mathrm{mL}$. In these determinations, the maximum measurable time was $300 \mathrm{~s}$ when using a concentration of $60 \mathrm{mg} / \mathrm{mL}$ of extract. Fig. 2 shows the concentrations that resulted in a clotting time $<300 \mathrm{~s}$ when the extract was incubated with PPP for $0.5 \mathrm{~min}$ to $20 \mathrm{~min}$. Only the results of incubation at $0.5 \mathrm{~min}$ are presented because there were no significant differences with other incubation times $(1,2,5,10,15,20 \mathrm{~min})$.

The hydroethanolic extract of $L$. furfuracea prolonged PT, APTT and TT in a concentration-dependent, unlike other plants with anticoagulant activity [58-61] L. furfuracea prolongs the three times of clotting. In Echinacea purpurea and Fragaria vesca, the coagulation times were prolonged to more than $600 \mathrm{~s}$ for APTT and more than $300 \mathrm{~s}$ for PT [61]; meanwhile, the Crataegus monogyna extract prolonged clotting times from 37.9 to $350.5 \mathrm{~s}$ for APTT and from 13.4 to $16.5 \mathrm{~s}$ for PT [58]. However, these species prolong clotting times in such a way that they act on factors IX, XI, and XII of the intrinsic pathway (APTT) and fVII of the extrinsic pathway (PT) of the in vitro coagulation system.

The $L$. furfuracea extract $(25 \mathrm{mg} / \mathrm{mL}$ ) continued to have the same concentration-dependent effect on TT, even when thrombin concentrations increased (Fig. 3). The L. furfuracea extract may act on thrombin since this enzyme participates in the final stage of secondary hemostasis and its inhibition is reflected in the prolongation of the three clotting times. It was found that even at the highest concentration of thrombin (40 $\mathrm{IU} / \mathrm{mL}$ ), the $L$. furfuracea extract maintained its anticoagulant effects and has a concentration-dependent effect, like that of heparin (positive control). The prolongation of thrombin time due to the orchid extract suggests that in vitro coagulation inhibition occurs in the final stage of hemostasis, in which thrombin (activated factor II) acts on fibrinogen to form fibrin. Due to exogenous thrombin is added to the study plasma, none of the hemostatic factors (II, V, VII, VIII, IX, X, XI, XII) participates in the formation of fibrin, with the exception of the fibrinogen (factor I) [62]. Under these conditions, the prolongation of the thrombin time can only be explained in two ways: that the extract inhibits thrombin or that the extract binds to fibrinogen preventing fibrin formation. In both cases, the extract inhibits the hemostatic effect of thrombin. On the other hand, if the extract had prolonged PT and APTT, but not TT, we would have focused our attention on common pathway factors, including factor II (prothrombin). However, the prolongation of TT suggests that the prolongation of PT and APTT can be explained in the same way as for TT, that is, the extract inhibits the hemostatic activity of thrombin, which, unlike the TT test, is generated in vitro after activation of FVII (PT) and FXII (APTT). 

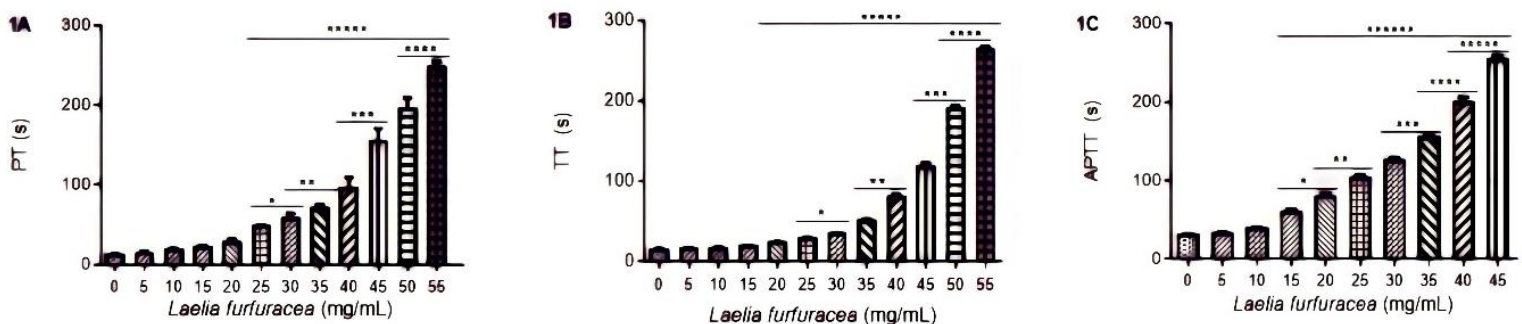

Fig. 2. Effect of the hydroethanolic extract of Laelia furfuracea on clotting times. 1A) prothrombin time (PT), 1B) thrombin time (TT), 1C) activated partial thromboplastin time (APTT) in platelet-poor plasma (PPP) samples from patients with thrombosis. $\mathrm{p}<0.05$. Asterisks represent significant differences between different groups.

From another point of view, the effect of $L$. furfuracea extract on thrombin may be due to the active compounds it may contain. Flavonoids have been shown to act as anticoagulants by competitively inhibiting thrombin [7] by interacting with the active site of the enzyme [51]. This suggests that more -OH groups in the $B$ ring of the structure of a flavonoid would increase the inhibition of thrombin [11], since thrombin has a much higher affinity for the proteins that are its physiological substrates (fibrinogen or protease-activated receptors (PAR) [7]. This means that these compounds mimic the structure of physiological substrates and bind reversibly to the free form of the enzyme in competition with the substrate of the thrombin active site [63]. A molecular coupling analysis partially explains the potential mechanism of interaction of polyphenols with the active site of thrombin. It was shown that the 3'-hydroxyl and 4'-hydroxyl group in the Ring B of the structure of a flavonoid, as well as the 3-hydroxyl residue in ring $\mathrm{C}$, are very important for the inhibition of thrombin activity [51]. Ring B and C in flavonoids can interact with thrombin anchor S1 and S2, while ring A only partially interacts with S3 [64]. This suggests that the 3'-hydroxyl group and the 4'-hydroxyl group on the B ring of a flavonoid form hydrogen bond with amino acids to form the S1 anchor, which means that the B ring with hydroxyl groups at the position of R1 and R2 can mimic the arginine residue in P1 of thrombin substrates [65].

In general, the polyphenols have numerous biological effects. They reduce the risk of cardiovascular diseases [66], and participate in neurovascular protection, including antiplatelet activity [67]. They can also increase the bioavailability of nitric oxide (NO), thus antagonizing the development of endothelial function; they decrease blood viscosity, plasma levels of vWF, fibrinogen, and FVII [68]. Flavonoids prevent platelet aggregation by inhibiting the intracellular signals of the pathways and the enzymatic activity of phospholipase C (FLC), phospholipase A2 (FLA2) and COX-1, as well as the signals of the initiation pathways of thromboxanes A2 (TXA2), ADP, thrombin, collagen receptors and integrin $\alpha \operatorname{IIb} \beta 3$ [69]. Flavonoids also attenuate the activation of GPIIb / IIIa [70].

Unfractionated heparin prolonged clotting times in a concentration-response-dependent manner. Besides, it presented a similar effect to the $L$. furfuracea extract, but unlike this, the heparin concentrations were less than $1 \mu \mathrm{g} / \mathrm{mL}$ (Table 2). In this study, the ATTP was prolonged $>300 \mathrm{~s}$ from $0.4 \mu \mathrm{g} / \mathrm{mL}$ of heparin, while the fractions of polyphenolic-polysaccharide isolated from the medicinal plant Erigeron canadensis $L$. required $390 \mu \mathrm{g} / \mathrm{mL}$, and the Unfractionated Heparin $1 \mu \mathrm{g} / \mathrm{mL}$ prolonged this same time [71]. On the other hand, the polyphenolic fractions of Sargassum sp. in the APTT values were lower compared to heparin [72]. 


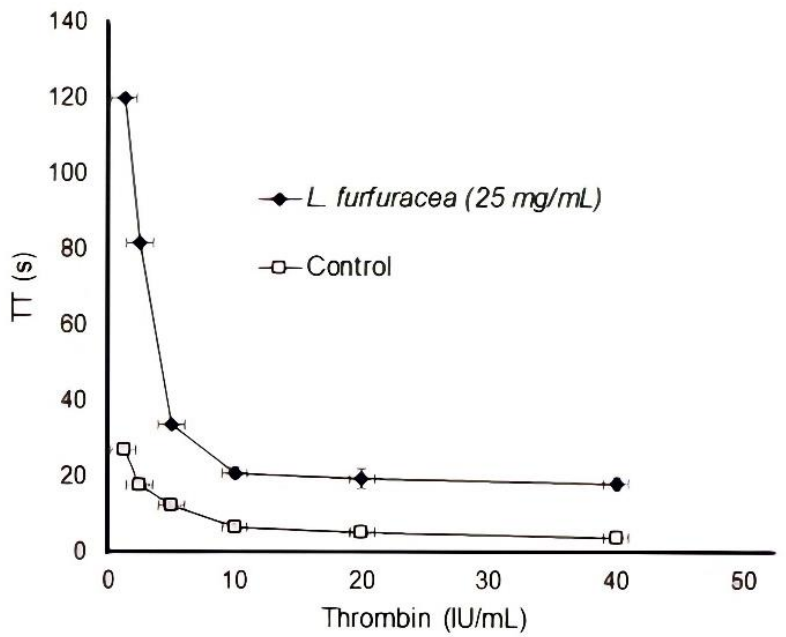

Fig. 3. Effect of the hydroethanolic extract of Laelia furfuracea $(25 \mathrm{mg} / \mathrm{mL})$ on thrombin kinetics in plateletpoor plasma (PPP) samples from patients with thrombosis.

Table 2. The concentration-dependent anticoagulant effect of unfractionated heparin (UFH) on clotting times.

\begin{tabular}{|c|c|c|c|}
\hline UFH $(\mu \mathbf{g} / \mathbf{m L})$ & PT $(\mathbf{s})$ & APTT $(\mathbf{s})$ & TT $(\mathbf{s})$ \\
\hline 0 & $12.6 \pm 0.9$ & $35.7 \pm 1.3$ & $17.1 \pm 1.0$ \\
\hline 0.01 & $12.5 \pm 0.6$ & $45.5 \pm 1.8$ & $16.9 \pm 0.7$ \\
\hline 0.02 & $12.6 \pm 0.6$ & $52.8 \pm 3.1$ & $17.2 \pm 0.3$ \\
\hline 0.04 & $14.2 \pm 0.3$ & $62.6 \pm 1.0$ & $17.4 \pm 0.3$ \\
\hline 0.06 & $12.3 \pm 0.6$ & $68.4 \pm 2.4$ & $17.4 \pm 0.6$ \\
\hline 0.08 & $12.1 \pm 0.4$ & $94.8 \pm 6.0^{* *}$ & $17.9 \pm 0.6$ \\
\hline 0.1 & $12.9 \pm 1.4$ & $111.3 \pm 3.4^{* *}$ & $17.9 \pm 0.7$ \\
\hline 0.2 & $13.2 \pm 1.0$ & $233.9 \pm 7.8^{* *}$ & $19.4 \pm 0.4$ \\
\hline 0.4 & $15.4 \pm 1.3$ & $>300$ & $19.6 \pm 0.3$ \\
\hline 0.6 & $18.0 \pm 2.5$ & $>300$ & $21.4 \pm 1.4$ \\
\hline 0.8 & $19.8 \pm 3.8$ & $>300$ & $42.1 \pm 8.2^{* *}$ \\
\hline 0.9 & $34.6 \pm 9.2 * *$ & $>300$ & $75.4 \pm 8.4 * *$ \\
\hline 1.0 & $83.6 \pm 5.9^{* *}$ & $>300$ & $108.3 \pm 11.2^{* *}$ \\
\hline
\end{tabular}

UFH: Unfractionated Heparin; PT: prothrombin time; APTT: activated partial thromboplastin time; TT: thrombin time. s: seconds; $\mathrm{p}<0.05$. Asterisks represent significant differences between different groups.

\section{Effect of organic fractions on coagulation times}

Of the five fractions evaluated, the fractions showed the greatest anticoagulant effect, in this order: ethyl acetate> butanol> water. The ethyl acetate fraction reached a clotting time greater than $300 \mathrm{~s}$ with a concentration of $30 \mathrm{mg} / \mathrm{mL}$ for TT, $28 \mathrm{mg} / \mathrm{mL}$ for PT and $15 \mathrm{mg} / \mathrm{mL}$ for APTT (Table 3). The apolar hexane and chloroform fractions prolonged clotting times to a lesser extent than the ethyl acetate fraction (Table 3). In species of other groups of plants, for example, the phenolic fractions of Taraxacum officinale prolong TT between 17 and $20 \mathrm{~s}$, but not the TP and APTT [73]; phenolic fractions of Elaeagnus rhamnoides prolong APTT, TP, and TT by 1-2 s [66]. In the present study, the five fractions of L. furfuracea prolonged the three 
clotting times to a greater extent compared to the aforementioned species, this could be due to the components that are present in the fractions of $L$. furfuracea and the aforementioned species.

\section{Conclusion}

The hydroethanolic extract and ethyl acetate fraction of $L$. furfuracea leaves prolong clotting times (PT, APTT and TT) depending on the concentration-response. The tentatively identified compounds in $L$. furfuracea hydroethanolic foliar extract belong to groups xanthine, carboxylic acid, amino acid, and phenolic compounds. Among phenolic compounds there are derivatives of phenolic acids and flavonoids mainly, which could be acting as anticoagulant active agents. The results of the hemostatic tests suggest that the action mechanism is on thrombin, but this hypothesis should be confirmed by further studies. Laelia furfuracea is a species with potential for the search of new anticoagulant compounds.

\section{Acknowledgements}

The financial support provided by Consejo Nacional de Ciencia y Tecnología (CONACYT, project 270428) and Instituto Politécnico Nacional (IPN, projects SIP-2016-RE/50, SIP-20170263, SIP-20180382, SIP-20195897). The scholarship grants from CONACYT and IPN to the first author for Ph. D. studies. The community of Santo Domingo Yanhuitlán, Oaxaca for the permission to collect the plant material.

\section{References}

1. Bijak, M.; Saluk, J.; Szelenberger, R.; Nowak, P. Chem.-Biol. Interact. 2016, 257, 35-45. DOI: https://doi.org/10.1016/j.cbi.2016.07.022

2. Zhang, H.; Tsao, R. Curr. Opin. Food Sci. 2016, 8, 33-42. DOI: https://doi.org/10.1016/j.cofs.2016.02.002

3. Scalbert, A.; Johnson, I. T.; Saltmarsh, M. Am J Clin Nutri. 2005, 81, 215S-217S. DOI: https://doi.org/10.1093/ajen/81.1.215S

4. Zern, T. L.; Fernandez, M. L.; J. Nutr. 2005, 135, 2291-2294. DOI: https://doi.org/10.1093/jn/135.10.2291

5. Majewska, W. M.; Czeczot, H. Pol. Merkuriusz Lek. 2012, 32, 4-50.

6. Zong, S.; Ji, J.; Li, J.; Yang, Q. H.; Ye, M. J. Food Drug. Anal. 2017, 25, 837-844. DOI: https://doi.org/10.1016/j.jfda.2016.08.011

7. Bijak, M.; Ponczek, M. B.; Nowak, P. Int. J. Biol. Macromol. 2014, 65, 129-135. DOI: https://doi.org/10.1016/j.ijbiomac.2014.01.023

8. Kee, N. L. A.; Mnonopi, N.; Davids, H.; Naud, R. J.; Frost, C. L. Afr. J. Biotechnol. 2008, 7, $217-$ 223.

9. Jiang, F.; Dusting, G. J. Curr. Vasc. Pharmacol. 2003, 1, 135-156.

10. Zhang, S.; Yin, T.; Ling, X.; Liang, H.; Zhao, Y. Electrophoresis. 2008, 29, 3391-3397. DOI: https://doi.org/10.1002/elps.200800174

11. Liu, L.; Ma, H.; Yang, N.; Tang, Y.; Guo, J.; Tao, W.; \& Duan, J. Thromb. Res. 2010, 126, e365e378. DOI: https://doi.org/10.1016/j.thromres.2010.08.006

12. Alvarado, I. Universidad Médica. 2013, 54, 338-352. DOI: https://doi.org/10.11144/Javeriana.umed54-3.fenc

13. Adams, R. L.; Bird, R. J. Nephrology. 2009, 1, 462-470.

14. Hossain, M. M. Fitoterapia. 2011, 82, 102-140. DOI: https://doi.org/10.1016/j.fitote.2010.09.007 
15. Cruz-García, G.; Solano, R.; Lagunez-Rivera, L. Rev. Bras. Farmacogn. 2014, 24, 153-158. DOI: https://doi.org/10.1016/j.bjp.2014.03.002

16. Cox, L. D. T. Bioagrociencias. 2013, 6, 4-7.

17. He, X.; Wang, X.; Fang, J.; Zhao, Z.; Huang, L.; Guo, H.; Zheng, X. J. Ethnopharmacol. 2017, 195, 20-38. DOI: https://doi.org/10.1016/j.jep.2016.11.026

18. Halbinger, F.; Soto, M. Orquídea, México. 1997. 15:1-160.

19. Hernández, F. UNAM, México. 1959, 375.

20. Yoshikawa, M.; Murakami, T.; Kishi, A.; Sakurama, T.; Matsuda, H.; Nomura, M.; Kubo, M. Chem. Pharma. Bull. 1998, 46, 886-888. DOI: https://doi.org/10.1248/cpb.46.886

21. Juan, L. I.; Shunxiang, L. I.; Huang, D.; Zhao, X.; Cai, G. Keji Daobao/ Science \& Technology Review. 2011, 29, 74-79. DOI: http://www.kjdb.org/EN/10.3981/j.issn.1000-7857.2011.18.012

22. Fan, C.; Wang, W.; Wang, Y.; Qin, G.; Zhao, W. Phytochemistry. 2001, 57, 1255-1258. DOI: https://doi.org/10.1016/S0031-9422(01)00168-6

23. Wang, Y.; Liu, J. J.; Li, Q.; Wang, Y.T.; Wang, C. M. Biotechnol. Lett. 2015, 37, 1-8. DOI: https://doi.org/10.1007/s10529-014-1647-6

24. Lu, B.; Xu, Y. M.; Zhang, H. M.; Li, T. J.; Qiu, Y. Pharm. J. Chin. Peoples Lib. Army. 2005, 21, $330-332$.

25. Jímarez-Montiel, M.; UNAM, México. 2009, 30-43.

26. Vergara-Galicial, J.; Castillo-España, P.; Villalobos-Molina, R.; Estrada-Soto, S. J. Appl. Pharm. Sci. 2013, 3, 034-037. DOI: https://doi.org/10.7324/JAPS.2013.3707

27. Vergara-Galicia, J.; Ortiz-Andrade, R.; Rivera-Leyva, J.; Castillo-España, P.; Ibarra, M. B.; Villalobos-Molina, R.; Ibarra-Barajas, M.; Gallardo-Ortiz, I.; Estrada-Soto, S. Fitoterapia. 2010, 81, 350-357. DOI: https://doi.org/10.1016/j.fitote.2009.10.009

28. Aguirre-Crespo, F.; Castillo-España, P.; Villalobos-Molina, R.; López-Guerrero, J. G.; EstradaSoto, S. Pharm. Biol. 2005, 43, 540-546. DOI: https://doi.org/10.1080/13880200500220839

29. Vergara-Galicia, J.; Ortiz-Andrade, R.; Castillo-España, P.; Ibarra-Barajas, M.; Gallardo-Ortiz, I.; Villalobos-Molina, R.; Estrada-Soto, S. Vasc. Pharmacol. 2008, 49, 26-31. DOI: https://doi.org/10.1016/j.vph.2008.04.002

30. Solano, R.; Huerta-Espinoza, H.; Cruz-García, G.; Ortíz-Rivero, F Phytotaxa. 2019, 402, 232. DOI: https://doi.org/10.11646/phytotaxa.402.5.2

31. Halbinger, F.; Soto, M. Orquídea. 1997, 15,1-160.

32. López-Pérez, A.; Barragán-Zárate, G. S.; Lagunez-Rivera, L.; Solano, R. Journal CIM. 2016, 4, 605-610.

33. https://es.worldthrombosisday.org/. accessed in March 2021.

34. Martínez-Murillo, C.; Aguilar-Arteaga, M. L.; Velasco-Ortega, E.; Alonso-González, R.; Castellanos-Sinco, H.; Romo-Jiménez, A.; Vargas-Ruíz, A.; Torres-Arreola, L.; Viniegra-Osorio, A. Rev. Med. Inst. Mex. Seguro Soc. 2011, 49, 437-449.

35. Mousa, S. A., in: Drug Discovery and Evaluation: Pharmacological Assays, Vol. 1, Franz, J., Ed., Springer, Berlin, 2015, 1-8. DOI: https://doi.org/10.1007/978-3-642-27728-3_151-1

36. Sayajit, D. S.; Zahid, L.; Alexander, I. G. Natural Products isolation. Ed. HUMANA PRESS. 2006, $48-52$

37. Mohammad, A. H.; Khulood, A. S.; Zawan, H.; Afaf, M. W.; Qasim, A. 1. R. Asian Pac. J Trop. Biomedic. 2013, 3, 705-710. DOI: https://doi.org/10.1016/S2221-1691(13)60142-2

38. Barragán-Zárate, G.S.; Lagunez-Rivera, L.; Solano, R.; Pineda-Peña, E. A.; Landa-Juárez, A. J.; Chávez-Piña, A. E.; Carranza-Álvarez, C.; Hernández-Benavidez, D. M. J. Ethnopharmacol. 2020, 253. DOI: $10.1016 /$ j.jep.2020.112632

39. Srinivasulu, C.; Ramgopal, M.; Ramanjaneyulu, G.; Anuradha, C. M.; Suresh, K. G. Biomed. Pharmacother. 2018, 108, 547-557. DOI: https://doi.org/10.1016/j.biopha.2018.09.069

40. Huang, L.; Lin, C.; Li, A.; Wei, B.; Teng, J.; Li, L. Nat. Prod. Commun. 2010, 5,1263-1266.

41. Cheemanapalli, S.; Mopuri, R.; Golla, R.; Anuradha, C. M. Biomed. Pharmacother. 2018, 108, 547-557. DOI: https://doi.org/10.1016/j.biopha.2018.09.069 
42. Shahzad, S.; Mateen, S.; Naeem, S. S.; Rizvi, W. Eur. J. Pharmacol. 2019, 849, 135-145. DOI: https://doi.org/10.1016/j.ejphar.2019.01.056

43. Kakkar, S.; Bais, S. ISRN Pharmacol. 2014, 1-9. DOI: https://doi.org/10.1155/2014/952943

44. https://pubchem.ncbi.nlm.nih.gov/compound/72. accessed in September 2021.

45. Campos, E. M., Stehle, P.; Simon, M. C. Nutrients. 2019, 11, 2260. DOI: https://doi.org/10.3390/nu11102260

46. Kim, D. C.; Ku, S. W.; Bae, J. S. BMB Reports. 2012, 45, 221-226. DOI: https://doi.org/10.5483/BMBRep.2012.45.4.221

47. https://pubchem.ncbi.nlm.nih.gov/compound/Rosmarinic-acid. accessed in September 2021.

48. Popov, A. M.; Osipov, A. N.; Korepanova, E. A.; Krivoshapko, O. N.; Artyukov, A. A. Biophysics. 2013, 58, 607-615. DOI: https://doi.org/10.1134/S0006350913050126

49. https://www.ebi.ac.uk/chebi/searchId.do?chebiId=CHEBI:50371, accessed in February 2021.

50. Lin, Z.; Fang, Y.; Huang, A.; Chen, L.; Guo, S.; Chen, J. Pharm. Biol. 2014, 52, 1429-1434. DOI: https://doi.org/10.3109/13880209.2014.895019

51. Shi, Z. H.; Li, N. G.; Tang, Y. P.;Wei, L.; Lian, Y.; Yang, J. P.; Hao, T.; Duan, J. A. Eur. J. Med. Chem. 2012, 54, 210-222. DOI: https://doi.org/10.1016/j.ejmech.2012.04.044

52. Yin, Z.; Zhang, Y.; Zhang, J; Wang, J.; Kang, W. Chem. Cent. J. 2018, 12, 126. DOI: https://doi.org/10.1186/s13065-018-0490-6

53. Khouya, T.; Ramchoun, M.; Hmidani, A.; Amrani, S.; Harnafi, H.; Benlyas, M.; Alem, C. Asian P. J. Trop. Biomed. 2015, 5, 636-644. DOI: https://doi.org/10.1016/j.apjtb.2015.05.011

54. https://www.ebi.ac.uk/chembl/compound report_card/CHEMBL1414/, accessed in February 2021

55. https://www.ebi.ac.uk/chembl/compound_report_card/CHEMBL37537/, accessed in February 2021

56. https://www.ebi.ac.uk/chembl/compound_report_card/CHEMBL324842/, accessed in February 2021.

57. https://www.ebi.ac.uk/chembl/compound report_card/CHEMBL487017/, accessed in February 2021.

58. Pawlaczyk, I. G. Biol. Macromol. 2018, 1-38. DOI: https://doi.org/10.1016/j.ijbiomac.2018.05.101

59. Pereira, B.; Brazón, J. J. Ethnopharmacol. 2015, 160, 6-13. DOI: https://doi.org/10.1016/j.jep.2014.11.022

60. Nsimba, M. M.; José, N. L.; Yumiko, H.; Chika, Y.; Toshiyuki, K. J. Ethnopharmacol. 2013, 148, 895-900. DOI: https://doi.org/10.1016/j.jep.2013.05.038

61. Pawlaczyk, I.; Czerchawski, L.; Pilecki, W.; Lamer, E. Z.; Gancarz, R. Carbohydr. Polym. 2009, 77, 568-575. DOI: https://doi.org/10.1016/j.carbpol.2009.01.030

62. Virgós, S. B.; Nebra, P. A. C.; Suárez, P. M. A.; Cornudella, L. R.; Portero, P. P. Hipertensión y Riesgo Vascular. 2008, 25, 4-8. DOI: https://doi.org/10.1016/S1889-1837(08)71724-0

63. Correia, D. S. M.; Sousa, E.; Duarte, B.; Marques, F.; Cunha, R. L. M.; Pinto, M. M. M. Eur. J. Med. Chem. 2011, 46, 2347-2358. DOI: https://doi.org/10.1016/j.ejmech.2011.03.016

64. Bjelakovic, G.; Stojanovic, I.; Bjelakovic, G.; Pavlovic, G.; Kocic, G.; Dakovic, A. M. Facta Univ. Ser. Med. Biol. 2002, 9, 201-206.

65. Bijak, M.; Joanna, S.; Pawel, N. Drug. Res. 2018, 75, 533-544.

66. Lis, B.; Jędrejek, D.; Stochmal, A.; Olas, B. Food Res. Int. 2018, 107, 605-612. DOI: https://doi.org/10.1016/j.foodres.2018.03.012

67. Olas, B.; Zuchowski, J.; Lis, B.; Skalski, B.; Kontek, B.; Grabarczyk, L.; Stochmal, A. Food Chem. 2018, 247, 39-45. DOI: https://doi.org/10.1016/j.foodchem.2017.12.010

68. Curin, Y.; Ritz, M.; Andriantsitohaina, R. Cardiovasc. Hematol. Agents Med. Chem. 2006, 4, 277-288. DOI: http://dx.doi.org/10.2174/187152506778520691

69. McMichael, M.; Anim. Med. 2012, 27, 40-45. 
70. Faggio, C.; Sureda, A.; Morabito, S.; Sanches-Silva, A.; Mocan, A.; Nabavi, S. F.; Nabavi, S. M. Eur. J. Pharmacol. 2017, 807, 91-101. DOI: https://doi.org/10.1016/j.ejphar.2017.04.009

71. López, J. A.; Rocha, H. A. O.; Rocha, H. A. O.; Almeida, M. D. G. J. Med. Food. 2019, 22, 384392. DOI: http://doi.org/10.1089/jmf.2018.0141

72. Pawlaczyk, I.; Czerchawski, L.; Kuliczkowski, W.; Karolko, B.; Pilecki, W.; Witkiewicz, W.; Gancarz, R. Thromb. Res. 2011, 127, 328-340. DOI: https://doi.org/10.1016/j.thromres.2010.11.031

73. Shobharani, P.; Nanishankar, V. H.; Halami, P. M.; Sachindra, N. M. Int. J. Biol. Macromol. 2014, 65, 542-548. DOI: https://doi.org/10.1016/j.ijbiomac.2014.02.005 
Table 3. Clotting times for thrombin time (TT), prothrombin time (PT), and activated partial thromboplastin time (APTT) in plasma of venous thromboembolic disease (VTE) patients incubated with organic fractions of Laelia furfuracea.

\begin{tabular}{|c|c|c|c|c|c|c|c|c|c|c|c|c|c|c|c|}
\hline \multirow[b]{2}{*}[\mathrm{mg}/\mathrm{mL}]{} & \multicolumn{5}{|c|}{ TT (s) } & \multicolumn{5}{|c|}{ PT (s) } & \multicolumn{5}{|c|}{ APTT (s) } \\
\hline & Hexanc & $\mathrm{CHCl}_{3}$ & EtOAc & $\mathrm{BuOH}$ & $\mathrm{H}_{2} \mathrm{O}$ & Hexanc & $\mathrm{CHCl}_{3}$ & EtOAc & $\mathrm{BuOH}$ & $\mathrm{H}_{2} \mathrm{O}$ & Hexane & $\mathrm{CHCl}_{3}$ & EtOAc & $\mathrm{BuOH}$ & $\mathrm{H}_{2} \mathrm{O}$ \\
\hline $\mathbf{0}$ & $15.7 \pm 0.4$ & $15.9 \pm 0.2$ & $16.5 \pm 0.3$ & $16.8 \pm 0.3$ & $16.6 \pm 0.3$ & $15.4 \pm 0.2$ & $15.2 \pm 0.2$ & $15.2 \pm 0.1$ & $15.2 \pm 0.3$ & $15.3 \pm 0.1$ & $30.5 \pm 0.4$ & $30.5 \pm 0.1$ & $31.2 \pm 1.1$ & $30.3 \pm 0.2$ & $31.8 \pm 1.3$ \\
\hline 1 & $10.8 \pm 0.3$ & $10.5 \pm 0.4$ & $17.4 \pm 0.3$ & $18.9 \pm 0.5$ & $17.4 \pm 0.4$ & $12.6 \pm 0.2$ & $9.7 \pm 0.2$ & $16.5 \pm 0.4$ & $15.6 \pm 0.2$ & $15.5 \pm 0.3$ & $32.7 \pm 0.4$ & $31.6 \pm 0.2$ & $36.9 \pm 1.4$ & $35.3 \pm 0.4$ & $34.0 \pm 0.7$ \\
\hline 2.5 & $11.2 \pm 0.2$ & $11.4 \pm 0.1$ & $18.1 \pm 0.4$ & $19.7 \pm 0.2$ & $18.3 \pm 0.2$ & $12.8 \pm 0.1$ & $10.6 \pm 0.4$ & $16.9 \pm 0.2$ & $16.6 \pm 0.2$ & $15.8 \pm 0.2$ & $33.5 \pm 0.4$ & $32.6 \pm 0.2$ & $44.4 \pm 3.1$ & $38.0 \pm 0.3$ & $37.8 \pm 2.1$ \\
\hline 5 & $11.5 \pm 0.1$ & $11.7 \pm 0.2$ & $18.5 \pm 0.4$ & $20.3 \pm 0.3$ & $19.9 \pm 0.4$ & $12.8 \pm 0.1$ & $11.6 \pm 0.2$ & $17.5 \pm 0.4$ & $18.5 \pm 0.3$ & $16.3 \pm 0.2$ & $36.1 \pm 0.4$ & $34.5 \pm 0.4$ & $87.3 \pm 7.9 *$ & $62.9 \pm 2.6$ & $54.3 \pm 1.8$ \\
\hline 10 & $11.6 \pm 0.1$ & $12.5 \pm 0.3$ & $20.1 \pm 0.3$ & $21.6 \pm 0.4$ & $23.8 \pm 0.7$ & $13.2 \pm 0.2$ & $12.3 \pm 0.2$ & $18.7 \pm 0.2$ & $19.7 \pm 0.5$ & $16.7 \pm 0.2$ & $41.1 \pm 0.9$ & $37.4 \pm 0.6$ & $159.5 \pm 7.7 *$ & $74.2 \pm 2.1^{*}$ & $67.2 \pm 1.8$ \\
\hline 15 & $12.2 \pm 0.2$ & $13.6 \pm 0.4$ & $35.0 \pm 3.9^{*}$ & $29.6 \pm 0.7$ & $30.5 \pm 0.6$ & $13.8 \pm 0.1$ & $13.5 \pm 0.4$ & $26.8 \pm 1.1$ & $26.7 \pm 1.4$ & $25.5 \pm 1.7$ & $44.8 \pm 1.2$ & $41.5 \pm 0.6$ & $>300$ & $93.1 \pm 2.3^{*}$ & $71.1 \pm 1.4^{*}$ \\
\hline 20 & $15.8 \pm 0.1$ & $17.5 \pm 0.4$ & $69.3 \pm 1.2 *$ & $34.7 \pm 0.6^{*}$ & $35.7 \pm 0.5^{*}$ & $14.7 \pm 0.2$ & $15.4 \pm 0.2$ & $31.4 \pm 1.4^{*}$ & $32.2 \pm 1.9^{*}$ & $32.5 \pm 1.7 *$ & $48.5 \pm 0.5$ & $45.6 \pm 0.3$ & $>300$ & $150.5 \pm 5.3^{*}$ & $80.4 \pm 0.9^{*}$ \\
\hline 22 & $16.3 \pm 0.2$ & $17.7 \pm 0.2$ & $92.6 \pm 2.5^{*}$ & $39.7 \pm 0.5 *$ & $40.9 \pm 0.6^{*}$ & $15.8 \pm 0.1$ & $16.7 \pm 0.2$ & $89.0 \pm 4.0 *$ & $42.7 \pm 2.5^{*}$ & $39.9 \pm 1.6^{*}$ & $51.4 \pm 1.0$ & $47.8 \pm 0.1$ & $>300$ & $197.1 \pm 6.2 *$ & $86.6 \pm 2.2^{*}$ \\
\hline 24 & $18.4 \pm 0.2$ & $18.5 \pm 0.4$ & $131.1 \pm 3.7 *$ & $53.9 \pm 0.3^{*}$ & $45.0 \pm 0.6^{*}$ & $16.8 \pm 0.1$ & $18.3 \pm 0.3$ & $142.4 \pm 7.2 *$ & $55.6 \pm 1.3^{*}$ & $43.6 \pm 2.9^{*}$ & $52.7 \pm 0.7$ & $52.7 \pm 0.5$ & $>300$ & $263.7 \pm 5.4^{*}$ & $104.5 \pm 3.6^{*}$ \\
\hline 26 & $20.4 \pm 0.2$ & $19.4 \pm 0.3$ & $191.1 \pm 7.9^{*}$ & $63.1 \pm 0.7 *$ & $51.3 \pm 1.1^{*}$ & $19.7 \pm 0.2$ & $19.5 \pm 0.5$ & $191.1 \pm 7.9^{*}$ & $61.3 \pm 3.3^{*}$ & $48.3 \pm 1.6^{*}$ & $50.7 \pm 0.1$ & $48.9 \pm 1.0$ & $>300$ & $>300$ & $118.6 \pm 2.4^{*}$ \\
\hline 28 & $25.6 \pm 0.2$ & $25.5 \pm 0.5$ & $297.7 \pm 1.8^{*}$ & $76.8 \pm 0.4^{*}$ & $65.2 \pm 1.9^{*}$ & $23.5 \pm 1.0$ & $24.6 \pm 1.9$ & $>300$ & $84.8 \pm 4.4^{*}$ & $58.5 \pm 0.6^{*}$ & $53.3 \pm 3.0$ & $51.9 \pm 0.9$ & $>300$ & $>300$ & $148.9 \pm 2.8^{*}$ \\
\hline 30 & $30.5 \pm 0.4$ & $32.8 \pm 0.4$ & $>300$ & $105.4 \pm 1.1 *$ & $87.6 \pm 1.7 *$ & $27.4 \pm 1.8$ & $28.6 \pm 1.2$ & $>300$ & $103.8 \pm 8.3^{*}$ & $80.0 \pm 0.6^{*}$ & $54.3 \pm 0.9$ & $51.1 \pm 1.0$ & $>300$ & $>300$ & $163.4 \pm 2.7^{*}$ \\
\hline
\end{tabular}

